\title{
MORPHOMETRIC CHARACTERISTICS AND COI HAPLOTYPE DIVERSITY OF ARCTODIAPTOMUS SPINOSUS (COPEDODA) POPULATIONS IN SODA PANS IN HUNGARY
}

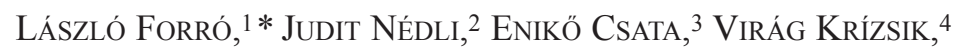 \\ Csilla BAlOGH ${ }^{2}$ and LÁszló G.-TóTH ${ }^{2,5}$
}

\begin{abstract}
${ }^{1}$ Department of Zoology, Hungarian Natural History Museum, Baross u. 13, H-1088 Budapest, Hungary 2Department of Hydrozoology, MTA Centre for Ecological Research, Balaton Limnological Institute, Klebelsberg K. u. 3, H-8237 Tihany, Hungary

${ }^{3}$ Hungarian Department of Biology and Ecology, Babes-Bolyai University, 400006 Cluj-Napoca, Clinicilor 5-7, Romania

${ }^{4}$ Laboratory of Molecular Taxonomy, Hungarian Natural History Museum, Ludovika tér 2-6, H-1082 Budapest, Hungary

${ }^{5}$ Institute of Regional Economics and Rural Development, Faculty of Economics and Social Sciences, Szent István University, Páter Károly út 1. H-2010 Gödöllő, Hungary
\end{abstract}

(Received: October 20, 2016; accepted: May 25, 2017)

\begin{abstract}
Arctodiaptomus spinosus (Daday, 1891) is a characteristic species of the soda pan zooplankton in the Great Hungarian Plain. The biogeographical distribution of the species is interesting, since its range expands from the Pannonian Biogeographic region to the other side of the Carpathians, occurring in saline lakes in Eastern Anatolia, Armenia, Iran and in temporary waters in Ukraine. Our investigations focused on the morphometric characteristics and the COI haplotype diversity of four Hungarian populations in the Kiskunság area. We detected substantial morphological differences between the Böddi-szék population and the rest of the sampling sites, however considerable differences were not observable in the COI haplotypes in the populations. The 20 animals investigated for COI haplotypes belonged to the same haplotype network. Tajima's D indicated departures from the neutral Wright - Fisher population model and suggested population expansion. The genetic composition of Arctodiaptomus spinosus populations in the Kiskunság area is rather uniform.
\end{abstract}

Keywords: Arctodiaptomus spinosus - morphology - COI haplotypes - sodic waters

\section{INTRODUCTION}

Arctodiaptomus spinosus is a characteristic zooplankton species of alkaline waters, its westernmost distribution area reaches the Neusiedler See, Seewinkel and surrounding soda pans in Austria. It is widespread and abundant in the soda pans of the Pannonian Plain (including the Great Hungarian Plain and the Little Hungarian Plain) and it can be found on the other side of the Carpathian mountain range in Ukraine. From the Balkan Peninsula no records are available but the species is known from Eastern Anatolia, Armenia and Iran [13, 18, 30]. The species has originally been described

\footnotetext{
*Corresponding author; e-mail address: forro.laszlo@nhmus.hu
} 
based on specimens collected in Lake Fertő (Neusiedler See) and in soda pans near Bugac [9].

Soda pans are typical habitats in the Pannonian Plain and they are present in high number in the Kiskunság area, in the middle of Hungary. Soda pans are characterised by low to medium salinity with marked seasonal changes throughout the year, excess of $\mathrm{Na}^{+}$and $\mathrm{HCO}_{3}^{-}$ions and alkaline $\mathrm{pH}(7.5-10.5)$. The geology and biology including composition, abundance and seasonal changes of zooplankton of the soda pans has been intensively studied previously [4, 12, 22, 27, 34]. Characteristic crustacean species in the soda pans are fairy shrimps like Branchinecta orientalis Sars, 1901, Branchinecta ferox (Milne-Edwards, 1840), Chirocephalus carnuntanus (Brauer, 1877), copepods like Arctodiaptomus spinosus and Arctodiaptomus bacillifer (Koelbel, 1885) and cladocerans like Daphnia magna Straus, 1820, Moina brachiata (Jurine, 1820) and Daphnia atkinsoni Baird, 1859. Cryptic speciation has been shown in the latter two species recently $[24,25]$.

Arctodiaptomus spinosus represents an important food source for aquatic bird species in the Kiskunság soda pans [2,3] and this abundant species has a prominent role in the food web, providing a bottom-up effect and structuring aquatic bird assemblages in spring [17]. The colour of Arctodiaptomus spinosus is bright red due to carotenoids (G.-Tóth L. unpublished data) in the studied soda pans. These pigments serve either as UV-photoprotection in the habitats without fish predators [15], while other factors like wind-induced turbulence and crowding may play role in their accumulation [32].

The number of the detected cryptic species increased to a great extent in the recent decades [26], and cryptic species discoveries among copepod crustaceans that were previously believed to be cosmopolitan are frequent, too. Support for the presence of cryptic taxa comes from molecular analyses $[8,14,19,21]$ and crossbreeding studies [23].

With this study we aimed to investigate morphological and genetic diversity within and between Arctodiaptomus spinosus populations from a geographically small region (Kiskunság) in the Great Hungarian Plain. We hypothesised that this area is a diversity hotspot in the Pannonian Plain since the suitable alkaline habitats for Arctodiaptomus spinosus are present in high number with diverse physicochemical characteristics in the Kiskunság area within the Carpathian basin. We also aimed to reveal the possible presence of cryptic taxa in Arctodiaptomus spinosus, or the opposite, to prove that genetically uniform populations are present in this region.

\section{MATERIAL AND METHODS}

Our study focused on the investigation of Arctodiaptomus spinosus populations from four soda pans in Central Hungary in the Kiskunság area: Kelemen-szék (120 ha,

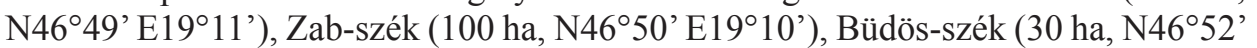
E19 ${ }^{\circ} 10^{\prime}$ ) at Szabadszállás and Böddi-szék ( 60 ha, N46 ${ }^{\circ} 46^{\prime}$ E19 $08^{\circ}$ ), size data taken from Tajima [35]. Zooplankton samples were collected with random netting by a 
$85 \mu \mathrm{m}$ mesh sized net from the pelagial zone of Zab-szék, Kelemen-szék, Büdös-szék and Böddi-szék (labelled wilh Z, K, BU and BO in the text) on the 4th August 2011. Samples were conserved in $95 \%$ ethanol on site and stored at $5{ }^{\circ} \mathrm{C}$ until further analysis.

Arctodiaptomus spinosus females were randomly selected from the total zooplankton samples for morphometric analysis. We measured 40 individuals from the Zabszék, 30 individuals from the Kelemen-szék, 30 individuals form the Büdös-szék and 30 individuals from the Böddi-szék under a NIKON YS2 light microscope. The measured variables were total body length (not including the setae at the end of the furca), body width (measured at the widest part of the first segment), length of the abdomen (measured from the genital segment to the end of the furca), body length (subtraction of the abdomen length from the total body length), length of the genital segment (measured alongside the longitudinal axis of the body), width of the genital segment (measured under the lateral spines), furca length, furca width, length of the inner seta on the furca, length of the outer seta on the furca, furthermore the number of carried eggs and the number of spermatophores attached to the females.

We performed Shapiro-Wilk normality tests on the data to check for parametric assumptions. Normally distributed data were further analysed by ANOVA and Tukey's test to discriminate between groups. Data that did not meet the assumption of normality were analysed by the Kruskal-Wallis test. All morphometric statistical analyses were performed in $\mathrm{R}$ [29].

For molecular analysis, adult females without eggs were randomly picked, but if the female carried eggs these were removed by needles from the individuals under a stereo microscope before proceeding to the DNA isolation. Total genomic DNA from single individuals was isolated using the $\mathrm{H} 3$ method [33]. Prior to DNA isolation, animals were soaked in TE buffer overnight. We used $50 \mu \mathrm{H}_{3}$ buffer in a grinded glass microtube to squash the animals gently with a grinded glass pestle. After this, the homogenate was transferred into a 2-ml microcentrifuge tube and the grinded glass tube and pestle were flushed into the same microcentrifuge tube with an additional $50 \mu 1 \mathrm{H}_{3}$ buffer. We added $20 \mu \mathrm{l}$ proteinase-K (Fermentas, $18.5 \mathrm{mg} / \mathrm{ml}$ ) to each homogenate and incubated the mixture at $60{ }^{\circ} \mathrm{C}$ with mild shaking for approximately 24 hours. Proteinase-K was denaturated by placing the tubes into a $95{ }^{\circ} \mathrm{C}$ waterbath for 10 minutes. PCR reactions to amplify the mitochondrial cytochrome oxidase I (COI) region were performed in $2 \times 25 \mu$ l volumes with $10 \mu \mathrm{l}$ of the DNA template, $5.775 \mu 1$ sterile milliQ water, $2.5 \mu 110 \times$ buffer with $20 \mathrm{mM} \mathrm{MgCl}_{2}, 3.125 \mu 12 \mathrm{mM}$ dNTP mix, $1.75 \mu \mathrm{l} 5 \mu \mathrm{M}$ primer each and $0.1 \mu 15 \mathrm{U} / \mu 1$ DreamTaq polymerase (Fermentas). The universal primers HCO1490 and LCO2198 [10] were used in the reactions. Settings for the amplification were: $94{ }^{\circ} \mathrm{C}-1 \mathrm{~min}, 40$ cycles $\left(94{ }^{\circ} \mathrm{C}-1 \mathrm{~min}\right.$, $\left.42.9^{\circ} \mathrm{C}-1 \mathrm{~min} 30 \mathrm{sec}, 72{ }^{\circ} \mathrm{C}-1 \mathrm{~min} 30 \mathrm{sec}\right)$ and $72{ }^{\circ} \mathrm{C}-6 \mathrm{~min}$.

Following the PCR reactions, products were cleaned (Roche Diagnostics, High Pure PCR Product Purification Kit) and sequencing was carried out from both directions according to the manufacturer's instructions by using BigDye Terminator v3.1 Cycle Sequencing Kit on an ABI 3130 Genetic Analyser with the same primer pair that was used in the PCRs. 

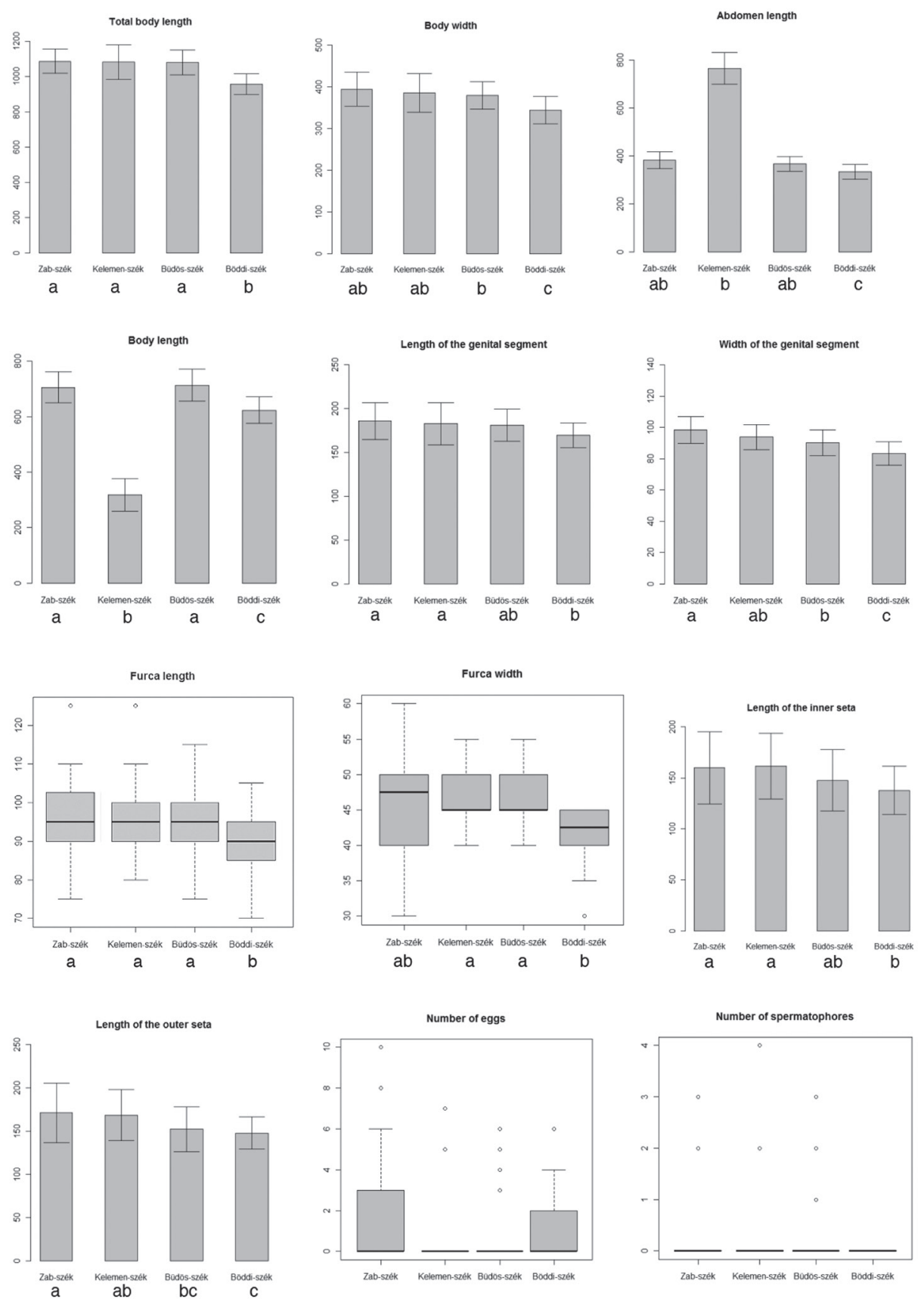

Fig. 1. The measured morphological variables with standard deviations of Arctodiaptomus spinosus individuals collected from soda pans in 2011. Left side scalebar indicates length in $\mu \mathrm{m}$ except for the number of eggs and spermatophores. Different letters indicate significant differences according to Tukey's test $(p<0.05)$ 
Manual check of automatic base calling and alignment of the sequences were performed in BioEdit 7.0.5.3 [15]. A minimum spanning network at $99 \%$ connection limit was generated in TCS 1.21 [5] based on the statistical parsimony cladogram estimation method [35]. Descriptive statistics and Tajima's D [33] to test for the neutrality of the mutations were calculated in DnaSP v5 [20]. Significance level of the latter statistics was calculated based on coalescent simulations without recombination with 5000 replicates.

\section{RESULTS}

\section{Morphological analyses}

The ANOVA for the total body length (Fig. 1) showed a significant difference $\left(\mathrm{F}_{3,126}=21.97, p<0.001\right)$ and Tukey's test pointed out that the Böddi-szék population was different from all the other sites $(p<0.001)$. ANOVA for the body width was significant $\left(\mathrm{F}_{3,126}=10.40, p<0.001\right.$, Fig. 1$)$ and Tukey's test differentiated between the Büdös-szék and the Böddi-szék $(p<0.01)$, Kelemen-szék and Böddi-szék $(p<0.001)$, furthermore the Zab-szék and the Böddi-szék $(p<0.001)$ populations. The length of the abdomen was significantly different $\left(\mathrm{F}_{3,126}=702.8, p<0.001\right)$ between sites and Tukey's test indicated the separation of the Böddi-szék from the other sites $(p<0.05)$ while the Kelemen-szék was also different from the Büdös-szék and Zab-szék $(p<0.001)$ population. In the case of the body length (Fig. 1), the ANOVA was also siginificant $\left(\mathrm{F}_{3,126}=250.90, p<0.001\right)$ and Tukey's test differentiated among populations of Böddi-szék, Kelemen-szék and all the other sites $(p<0.001)$. The length of the genital segment (Fig. 1) was significantly different $\left(\mathrm{F}_{3,126}=4.04, p<0.01\right)$ and Tukey's test indicated the differentiation of the Zab-szék and Böddi- szék populations. The ANOVA for the width of the genital segment was significant $\left(\mathrm{F}_{3,126}=20.42, p<0.001\right)$ while Tukey's test pointed out the Böddi-szék as different from all the other sites $(p<0.01)$ and indicated differentiation between the Zab-szék and the Büdös-szék $(p<0.001)$ populations. For the furca length the Kruskal-Wallis test showed significant differences between the populations $\left(X^{2}=12.08, d f=3, p<0.01\right)$ and also the furca width proved to be significantly different among sampling sites $\left(X^{2}=23.52\right.$, $d f=3, p<0.001$ ) (Fig. 1). The length of the inner seta on the furca differed significantly (ANOVA: $\mathrm{F}_{3,126}=4.10, p<0.01$ ) and Tukey's test differentiated between the Böddi-szék and Kelemen-szék $(p<0.05)$ and the Böddi-szék and Zab-szék $(p<0.05)$ populations. The length of the outer seta on the furca was also different between sites $\left(\mathrm{F}_{3,126}=5.58, p<0.01\right)$ and Tukey's test indicated differentiation between the Böddiszék and Zab-szék $(p<0.01)$, Böddi-szék and Kelemen-szék $(p<0.05)$ furthermore between the Büdös-szék and Zab-szék $(p<0.05)$ populations. The Kruskal-Wallis test did not indicate a difference between populations collected from different sites in the number of eggs carried $\left(X^{2}=5.74, d f=3, p=0.12\right)$ and in the number of the spermatophores attached to the females $\left(X^{2}=5.36, d f=3, p=0.15\right)$ (Fig. 1). 


\section{DNA analysis}

After the alignment of the forward and reverse sequences we obtained $656 \mathrm{bp}$ fragments of the mitochondrial COI gene with 9 singleton sites (unique occurrence of different character state of the nucleotides), 2 parsimony informative site (each distinct character state occurring at least with a frequency of two) and 10 different haplotypes among the 20 investigated individuals. GenBank Accession numbers can be found in Table 1. Descriptive statistics, diversity indices and Tajima's D for the populations are reported in Table 2.

All the 10 detected haplotypes contributed to the same haplotype network (Fig. 2) The A1 haplotype was detected in nine animals, it had the highest number of connections and this haplotype was present in each population. Haplotype A2 was detected in the Böddi-szék and Zab-szék populations while haplotype A3 was present in the

Table 1

The studied haplotypes of Arctodiaptomus spinosus from the Kiskunság area

\begin{tabular}{|c|c|c|c|}
\hline Ind & HID & Site & GenBank AN \\
\hline 1 & A1a & BU & KC660055 \\
\hline 2 & A1b & BU & KC660058 \\
\hline 3 & A1c & BU & KC660059 \\
\hline 4 & A1d & K & KC660060 \\
\hline 5 & A1e & K & KC660061 \\
\hline 6 & A1f & BO & KC660065 \\
\hline 7 & A1g & BO & KC660066 \\
\hline 8 & A1h & BO & KC660067 \\
\hline 9 & A1i & Z & KC660071 \\
\hline 10 & A2a & BO & KC660069 \\
\hline 11 & A2b & Z & KC660074 \\
\hline 12 & A3a & BU & KC660057 \\
\hline 13 & A3b & Z & KC660070 \\
\hline 14 & A10 & K & KC660063 \\
\hline 15 & A8 & K & KC660062 \\
\hline 16 & A9 & K & KC660064 \\
\hline 17 & A6 & Z & KC660072 \\
\hline 18 & A5 & BO & KC660068 \\
\hline 19 & A4 & BU & KC660056 \\
\hline 20 & A7 & Z & KC660073 \\
\hline
\end{tabular}

Ind = individual, HID = haplotype identification, the numbers correspond to haplotypes in Figure 2. Site $=$ site codes: BO - Böddi-szék, K - Kelemen-szék, Z - Zab-szék, BU - Büdös-szék. GenBank Accession Numbers are given in the last column. 
Table 2

Descriptive statistics, diversity indices and Tajima's D for the populations

\begin{tabular}{|c|c|c|c|c|c|c|c|}
\hline Pop & $n$ & $h$ & $S$ & Hd \pm 1 S.D. & $\pi \pm 1$ S.D. & $\mathrm{D}_{\mathrm{T}}$ & $\mathrm{pD}_{\mathrm{T}}$ \\
\hline $\mathrm{All}$ & 20 & 10 & 11 & $0.8 \pm 0.089$ & $0.00217 \pm 0.00048$ & -1.915 & 0.0146 \\
\hline $\mathrm{BO}$ & 5 & 3 & 2 & $0.7 \pm 0.218$ & $0.00122 \pm 0.00046$ & -0.973 & 0.4494 \\
\hline $\mathrm{K}$ & 5 & 4 & 6 & $0.9 \pm 0.161$ & $0.00396 \pm 0.00112$ & -0.668 & 0.4190 \\
\hline $\mathrm{BU}$ & 5 & 3 & 2 & $0.7 \pm 0.218$ & $0.00122 \pm 0.00046$ & -0.973 & 0.4618 \\
\hline $\mathrm{Z}$ & 5 & 5 & 4 & $1 \pm 0.126$ & $0.00244 \pm 0.00047$ & -1.094 & 0.3052 \\
\hline
\end{tabular}

Pop = population identifier, $n=$ number of individuals sequenced in a population, $h=$ number of haplotypes, $S=$ number of segregating sites, $\mathrm{Hd} \pm 1$ S.D. = haplotype diversity plus or minus one standard deviation, $\pi \pm 1$ S.D. = average pairwise distance, plus or minus one standard deviation, $D_{\mathrm{T}}=$ Tajima's $\mathrm{D}, \mathrm{p} D_{\mathrm{T}}=$ probability of $D_{\mathrm{T}} \neq 0$ as determined by coalescent simulation.

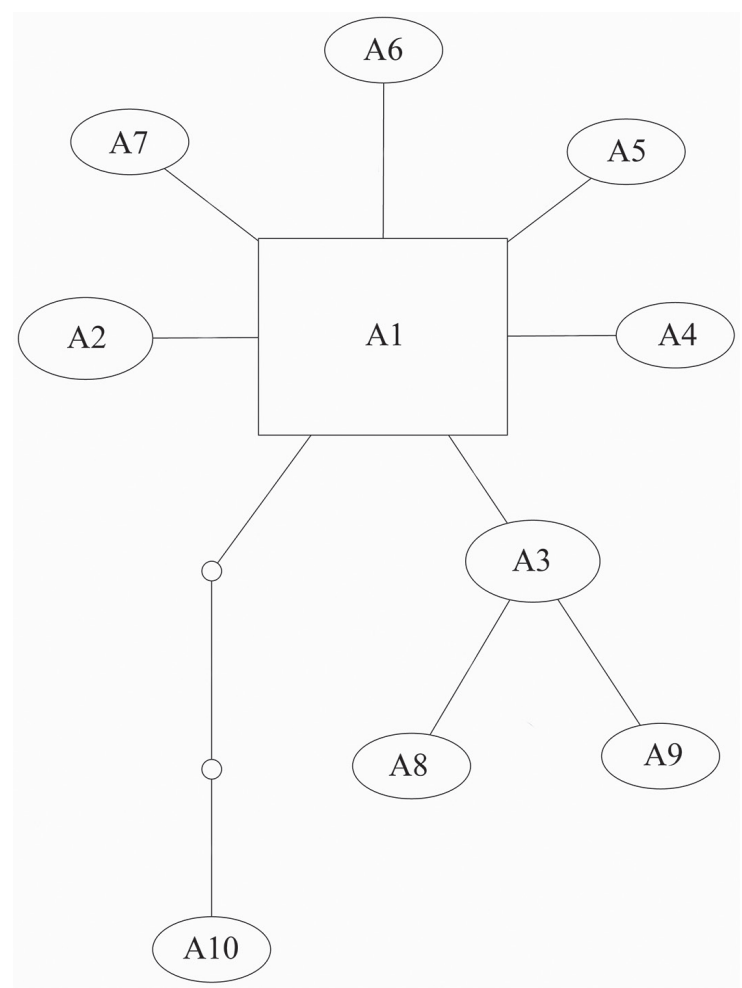

Fig. 2. COI haplotype network of twenty A. spinosus specimens at $99 \%$ connection limit. A1-A10: ten different $A$. spinosus haplotypes. The haplotypes with the highest mutational step numbers (A8, A9 and A10) originated from the Kelemen-szék population. The size of the ellipsoids and the rectangle is proportional to the number of occurrences of the given haplotype 
Büdös-szék and Zab-szék. The other haplotypes (A4-A10) were revealed only form one individual/site each. Haplotypes A8, A9 and A10 that were in the farthest distance from the A1 haplotype regarding the number of mutational steps were found in the Kelemen-szék population.

\section{DISCUSSION}

The Böddi-szék population differed strikingly from the other populations in morphometric characteristics. Females in the Böddi-szék were shorter and narrower than in the other sites, their abdomen, body length and width of the genital segment was shorter as well. After all the Böddi-szék individuals were smaller than individuals from the other sampling sites. It can happen that the size of the animals increases throughout the breeding season but in our case the samples originated from the same sampling dates, so this explanation for the difference between the Böddi-szék and other populations can be excluded. Animals in the Kelemen-szék had exceptionally long abdomens and short body length. This phenomenon is rather interesting and requires further investigation.

The discrepancy among the Böddi-szék, Kelemen-szék and the rest of the populations can be either genetically encoded or simply the result of phenotypic plasticity explained by between-site differences of environmental factors that were not investigated in the present study.

Despite the morphological differences, we did not detect substantial DNA divergence within the species, therefore we can conclude that Arctodiaptomus spinosus populations within the Kiskunság area are probably not affected by cryptic speciation. Regarding haplotype occurrences, the population is genetically diverse in the Kiskunság. Haplotype diversity in the total population was higher than and comparable to Ponto-Caspian cladoceran and amphipod populations, respectively [7]. Presumably with increased sample size we would detect even more haplotypes.

At the same time, the mean number of differences between pairwise haplotype comparisons (nucleotide diversity) was low, therefore the population can be considered as rather uniform. Nucleotide diversity was lower in the Arctodiaptomus spinosus than in cladoceran and amphipod populations from the Ponto-Caspian region [7].

Dormancy in copepods is a widespread phenomenon [10]. They produce subitaneous eggs in stable environments, while diapausing eggs with a different chorion structure [31] are produced to survive desiccation, freezing and other harsh conditions. Direct evidence for dormant stages of Arctodiaptomus spinosus was not yet reported in the literature but since it occupies habitats that occasionally dry out, presumably dormant propagules are produced by the species frequently and in high amounts. Copepod subitaneous eggs are able to maintain viability after passing through larval and adult fish guts $[1,6]$ and viable copepod eggs were recovered from the faeces of killdeer (Charadrius vociferus Linnaeus, 1758) [28]. Dormant propagules of Arctodiaptomus spinosus are presumably capable of passive dispersal via 
avian vectors and this might have been the way of colonisation of the Pannonian Plain or the other habitats in Ukraine and Turkey. It is unclear from where the species originates but the significant Tajima's D for the total Kiskunság population indicates that we can reject the neutral Wright-Fisher model and the negative value of it suggests population expansion and/or purifying selection. Supposedly Kiskunság populations of Arctodiaptomus spinosus still increases genetic diversity after the arrival of the founding population.

Herewith we clarified the COI haplotype characteristics of some Arctodiaptomus spinosus populations in the Kiskunság and provided data for comparison with future studies that should focus on a phylogenetic and population genetic comparison between the Pannonian populations and the populations from Turkey and from the Eastern side of the Carpathian mountain range.

\section{ACKNOWLEDGEMENTS}

This research was financially supported by the OTKA-NIH CNK 80140 grant of the Hungarian Scientific Research Fund (OTKA) and the GINOP-2.3.2.15_2016_00019 grant. E. Csata thanks to the training program of the Balaton Limnological Institute of the MTA Centre for Ecological Research. We thank Henriette Szabó, Tünde P. Klein, Mária Tuschek, Gyula Zsolt Keresztes and Balázs Németh for their help with the sample collection and DNA labwork.

\section{REFERENCES}

1. Bartholmé, S., Samchyshyna, L., Santer, B., Lampert, W. (2005) Subitaneous eggs of freshwater copepods pass through fish guts: Survival, hatchability, and potential ecological implications. Limnology and Oceanography 50, 923-929.

2. Boros, E., Bánfi, S., Forró, L. (2006) Anostracans and microcrustaceans as potential food sources of waterbirds on sodic pans of the Hungarian plain. Hydrobiologia 567, 341-349.

3. Boros, E., Forró, L., Gere, G., Kiss, O., Vörös, L., Andrikovics, S. (2008) The role of aquatic birds in the regulation of trophic relationships of continental soda pans in Hungary. Acta Zool. Acad. Sci. Hung. 54, 189-206.

4. Boros, E., V.-Balogh, K., Vörös, L., Horváth, Z. (2017) Multiple extreme environmental conditions of intermittent sodapans in the Carpathian Basin (Central Europe). Limnologica 62, 38-46.

5. Clement, M., Posada, D., Crandall, K. A. (2000) Tcs: A computer program to estimate gene genealogies. Mol. Ecol. 9, 1657-1660.

6. Conway, D. V. P., McFadzen, I. R. B., Tranter, P. R. G. (1994) Digestion of copepod eggs by larval turbot Scophthalmus maximus and egg viability following gut passage. Marine Ecol. Progr. Series 106, 303-309.

7. Cristescu, M. E. A., Hebert, P. D. N., Onciu, T. M. (2003) Phylogeography of Ponto-Caspian crustaceans: A benthic-planktonic comparison. Molecular Ecology 12, 985-996.

8. da Costa, K. G., Vallinoto, M., da Costa, R. M. (2011) Molecular identification of a new cryptic species of Acartia tonsa (copepoda, acartiidae) from the Northern coast of Brazil, based on mitochondrial COI gene sequences. J. Coastal Res. 64, 359-363.

9. Daday, J. (1890) A magyarországi Diaptomus-fajok átnézete (Conspectus Diaptomorum Faunae Hungaricae). Természetrajzi Füzetek 13, 114-143.

10. Dahms, H.-U. (1995) Dormancy in the copepoda - an overview. Hydrobiologia 306, 199-211. 
11. Folmer, O., Black, M., Hoeh, W., Lutz, R., Vrijenhoek, R. (1994) DNA primers for amplification of mitochondrial cytochrome c oxidase subunit I from diverse metazoan invertebrates. Mol. Marine Biol. Biotechnol. 3, 294-297.

12. Forró, L. (1989) Composition and seasonal changes of the microcrustacean fauna of sodic waters near Fülöpháza (Kiskunság National Park, Hungary). Miscellanea Zool. Hung. 5, 33-41.

13. Gaviria, S. (1998) Checklist and distribution of the free-living copepods (Arthropoda: Crustacea) from Austria. Ann. Naturhist. Museums Wien 100, 539-594.

14. Goetze, E. (2003) Cryptic speciation on the high seas; global phylogenetics of the copepod family Eucalanidae. Proc. Roy. Soc. London. Series B: Biol. Sci. 270(1531), 2321-2331.

15. Hairston, N. G. J. (1981) The interaction of salinity, predators, light and copepod color. Hydrobiologia $81,151-158$.

16. Hall, T. A. (1999) Bioedit: A user-friendly biological sequence alignment editor and analysis program for windows 95/98/nt. Nucl. Acids. Symp. Ser. 41, 95-98.

17. Horváth, Z., Vad, C. F., Vörös, L., Boros, E. (2013) The keystone role of anostracans and copepods in European soda pans during the spring migration of waterbirds. Freshwater Biol. 58, 430-440.

18. Kiefer, F. (1971) Revision der bacillifer-Gruppe der Gattung Arctodiaptomus Kiefer (Crustecea Copepoda: Calanoida). Memorie dell Istituto Italiano di Idrobiologia 27, 113-267.

19. Lee, C. E. (2000) Global phylogeography of a cryptic copepod species complex and reproductive isolation between genetically proximate "populations". Evolution 54, 2014-2027.

20. Librado, P., Rozas, J. (2009) Dnasp v5: A software for comprehensive analysis of DNA polymorphism data. Bioinformatics 25, 1451-1452.

21. Marrone. F., Lo Brutto, S., Hundsdoerfer, A. K., Arculeo, M. (2013) Overlooked cryptic endemism in copepods: Systematics and natural history of the calanoid subgenus Occidodiaptomus Borutzky 1991 (Copepoda, Calanoida, Diaptomidae). Mol. Phylogen. Evol. 66, 190-202.

22. Megyeri, J. (1959) Comparative hydrobiological investigations of the sodic waters of the Hungarian Plain. Acta Acad. Paedagog. Szegediensis 1959/II: 91-170 (In Hungarian).

23. Monchenko, V. I. (2000) Cryptic species in Diacyclops bicuspidatus (Copepoda:Cyclopoida): Evidence from crossbreeding studies. Hydrobiologia 417, 101-107.

24. Nédli, J., De Meester, L., Major, Á., Schwenk, K., Szivák, I., Forró, L. (2014) Salinity and depth as structuring factors of cryptic divergence in Moina brachiata (Crustacea: Cladocera). Fund. Appl. Limnol. 184, 69-85.

25. Petrusek, A., Tollrian, R., Schwenk, K., Haas, A., Laforsch, C. (2009) A "crown of thorns" is an inducible defense that protects Daphnia against an ancient predator. NAS 106, 2248-2252.

26. Pfenninger, M., Schwenk, K. (2007) Cryptic animal species are homogeneously distributed among taxa and biogeographical regions. BMC Evol. Biol. 7, 121.

27. Ponyi, J. (1961) Az alföldi szikes vizek zoológiai kutatásának helyzete. (Zoologische Erforschung der Natrongewässer der grossen ungarischen Tiefebene). Állattani Közlemények 48, 117-124.

28. Proctor, V. W., Malone, C. R., DeVlaming, V. L. (1967) Dispersal of aquatic organisms: Viability of disseminules recovered from the intestinal tract of captive killdeer. Ecology 48, 672-676.

29. R Development Core Team. (2011) R: A language and environment for statistical computing. R Foundation for Statistical Computing.

30. Samchyshyna, L. (2008) Ecological characteristic of calanoids (Copepoda, Calanoida) of the inland waters of Ukraine. Vestnik Zool. 42, e-32-e-37.

31. Samchyshyna, L., Santer, B. (2010) Chorion structure of diapause and subitaneous eggs of four diaptomid copepods (Calanoida, Diaptomidae): SEM observations. Vestnik Zool. e-26.

32. Schneider, T., Herzig, A., Koinig, K. A., Sommaruga, R. (2012) Copepods in turbid shallow soda lakes accumulate unexpected high levels of carotenoids. PLoS ONE 7, e43063.

33. Schwenk, K., Sand, A., Boersma, M., Brehm, M., Mader, E., Offerhaus, D., Spaak, P. (1998) Genetic markers, genealogies and biogeographic patterns in the cladocera. Aquatic Ecol. 32, 37-51.

34. Szabó, A., Korponai, K., Kerepesi, Cs., Somogyi, B., Vörös, L., Bartha, D., Márialigeti, K., Felföldi, T. (2017) Sodapans of the Pannonian steppe harbor unique bacterial communities adapted to multiple extreme conditions. Extremophiles 21, 639-649. 
35. Tajima, F. (1989) Statistical method for testing the neutral mutation hypothesis by DNA polymorphism. Genetics 123, 585-595.

36. Templeton, A.R., Crandall, K. A., Sing, C. F. (1992) A cladistic analysis of phenotypic associations with haplotypes inferred from restriction endonuclease mapping and DNA sequence data. Iii. Cladogram estimation. Genetics 132, 619-633.

37. Vörös. L., Boros, E., Schmidt, A., V.-Balogh, K., Németh, B., Somogyi, B., Mózes, A. (2006) Physical and chemical environment of phytoplankton in soda pans having white coloured water. Hidrológiai Közlöny 86, 139-141. 